\title{
Prophetic Guidance in The Prevention of Diseases and Outbreaks
}

Samy Mohamed Elsahker Abdelazeez, Syed Mohammad Chaedar Syed Abdurrahman Al-Yahya, Nidzamuddin Zakaria

To Link this Article: http://dx.doi.org/10.6007/IJARBSS/v11-i12/11877

DOI:10.6007/IJARBSS/v11-i12/11877

Received: 10 October 2021, Revised: 13 November 2021, Accepted: 30 November 2021

Published Online: 17 December 2021

In-Text Citation: (Abdelazeez et al., 2021)

To Cite this Article: Abdelazeez, S. M. E., Al-Yahya, S. M. C. S. A., \& Zakaria, N. (2021). Prophetic Guidance in The Prevention of Diseases and Outbreaks. International Journal of Academic Research in Business and Social Sciences, 11(12), 1358-1365.

Copyright: (C) 2021 The Author(s)

Published by Human Resource Management Academic Research Society (www.hrmars.com)

This article is published under the Creative Commons Attribution (CC BY 4.0) license. Anyone may reproduce, distribute, translate and create derivative works of this article (for both commercial and non0-commercial purposes), subject to full attribution to the original publication and authors. The full terms of this license may be seen at: http://creativecommons.org/licences/by/4.0/legalcode

Vol. 11, No. 12, 2021, Pg. 1358 - 1365

Full Terms \& Conditions of access and use can be found at http://hrmars.com/index.php/pages/detail/publication-ethics 


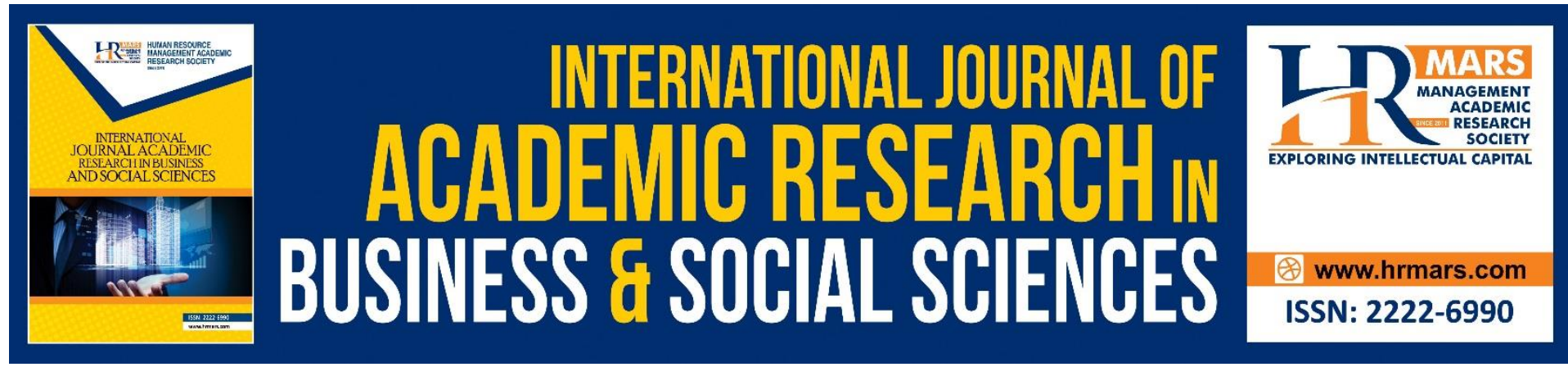

\title{
Prophetic Guidance in The Prevention of Diseases and Outbreaks
}

\author{
Samy Mohamed Elsahker Abdelazeez, Syed Mohammad \\ Chaedar Syed Abdurrahman Al-Yahya, Nidzamuddin Zakaria \\ Faculty of Quranic and Sunnah Studies Universiti Sains Islam Malaysia (USIM) \\ Email: Samymo1957@gmail.com
}

\begin{abstract}
Following the Prophetic guidance to prevent diseases and outbreaks is the best approach to mitigate the crises that may befall someone and maintain his health. Health is of great significance in one's life. It is a religious duty because it is necessary for the performance of one's religious duties in the required manner. This is the research problem. The performance of prayer, fasting, pilgrimage, seeking knowledge, and earning obligatory income requires a healthy body and mind. Similarly, all forms of work, such as trade, manufacturing, and others, require a healthy and sound body. Therefore, the Apostle (pbuh) included health as a legal requirement that must be maintained by Muslims. This study aims to explain the Prophetic guidance on how to prevent the body from falling ill through Prophetic teachings that relate to health. This study employed the inductive approach to gain comprehensive understanding on the topic. It also employed the analytical approach to obtain results relevant to the research topic. Among the results of the study is to declare and confirm that the new Coronavirus pandemic can only be mitigated by following the guidance of the Prophet (pbuh). Therefore, it is necessary to spread awareness about the guidance of the Prophet (pbuh) on how to prevent diseases and outbreaks by reminding of the importance of purity, cleanliness, and environmental preservation in every aspect of life, especially in food and beverage. This way, illness can be prevented before it befalls.
\end{abstract}

Keywords: Prophetic Guidance, Health, Prevention, Diseases, Outbreaks.

Preface

The purpose of every fard (mandatory), wajib (obligatory), sunnah (recommended), and mustahab (recommended) duty is at once two-fold: ta'abbudi (devotional) and health (șihhi). Both may be obscure to us, but the passing of time and continued progress of science push the learned individual to believe in Islam as the true religion, and that the Prophet Muhammad (pbuh) was the first teacher of mankind. Thus, you may see banners displaying "Muhammad (pbuh) was the first teacher of mankind" on the main streets of the United States of America and other parts of the world. This is after they are assured that, following the Corona pandemic, the only way to prevent diseases and outbreaks is to practice the teachings of our Prophet Muhammad (pbuh), which maintain and even boost health. Allah says, "We will show them Our signs in the universe and within themselves until it becomes 
clear to them that this Quran is the truth. Is it not enough that your Lord is a Witness over all things?" (Fușșilat: 53).

\section{Introduction}

None are safe from the effects of the global pandemic. The entire world suffers from the novel Coronavirus pandemic, thus stressing the necessity to follow the Prophet's guidance, whether physical or psychological, in the prevention of diseases and outbreaks. Likewise, such a guidance indicates the scientific miracles of Islam, which can highlight and elevate the value of this religion revealed from God. The Corona pandemic confirms that the only method to prevent diseases and outbreaks is to practice the teachings of our Prophet Muhammad (pbuh). They encompass all the factors that lead to the preservation and improvement of health and prevent the spread of diseases and outbreaks with clear practical and scientific steps reached by modern science in the treatment of diseases and outbreaks.

\section{Prophetic Guidance in the Prevention of Diseases Prevention at Home}

One who observes the Prophetic tradition shall find that it does not confront outbreaks and diseases with supplication or prayer alone, but he shall also follow the practical commandments of the Apostle of Allah (pbuh). These include ablution before and after a meal; not dipping one's hand in a water vessel after waking up for he did not know where his hand was while he slept; encouraging medication; and locking doors at night. All these have preventative benefits.

The Apostle of Allah (pbuh) said, "Shut your door and make mention of Allah's name, for the devil does not open a door which has been shut; extinguish your lamp and make mention of Allah's name; tie up your waterskin and mention Allah's name; and cover up your vessel even by a piece of wood that you just put on it, and make mention of Allah's name" (Abu Dawud, 2009, p. 30).

\section{Maintain Physical Health}

Allah created mankind in the best of form. He also bestowed upon them the senses and limbs and did not leave them without any care. Every human limb is tied to a devotional ruling whose purpose is to maintain its optimal performance. For example, ablution cleans those limbs that are exposed to pollution. Allah The Exalted says, "O believers! When you rise up for prayer, wash your faces and your hands up to the elbows, wipe your heads, and wash your feet to the ankles. And if you are in a state of [full] impurity, then take a full bath. But if you are ill, on a journey, or have relieved yourselves, or have been intimate with your wives and cannot find water, then purify yourselves with clean earth by wiping your faces and hands. It is not Allah's Will to burden you, but to purify you and complete His favor upon you, so perhaps you will be grateful." (al-Ma'idah: 6)

Therefore, washing the limbs mentioned in the noble verse purifies, cleans, and rids them of germs.

dr. Dr. Hamid al-Ghawwabi said, "Diseases are transmitted to humans in three ways: through the mouth, inhalation, or the skin. Ablution cleanses all these areas" (al-Ghawwabi, 1967, p. 86). For this reason, the Apostle (pbuh) encourages Muslims to perform ablution and explains its steps, as narrated by Imam al-Bukhari in an authentic hadith: 'Uthman ibn 'Affan narrated that the Prophet (pbuh) asked for a vessel of water and to pour it on his two noble hands thrice, and he washed them. He then dipped his right hand in the vessel and rinsed his mouth 
and inhaled and blew water out of his nose. He then washed his face thrice, his hands up to his elbows thrice, his head, and finally his legs up to the ankles thrice. 'Uthman then said, "The Apostle (pbuh) said, 'Whosoever performs ablution like I did and then prays two rak'ah of prayer in which he does not invalidate his purity, his past sins will be forgiven."' (Al-Bukhari, 2002, 1/48).

Dr. Gharib Jum'ah said, "One of the most significant preventative measures against skin diseases is washing the face, hands, and ears. Microbes, parasites, and some types of worms and fungi enter the human body through rashes caused by poor hygiene" (Jum ah, 2007, p. 50).

- Taking a bath to be ritually pure: Islam requires taking a bath after being junub (ritually impure due to sexual intercourse or seminal discharge). Allah The Exalted says, "They ask you [O Prophet] about menstruation. Say, "Beware of its harm! So keep away, and do not have intercourse with your wives during their monthly cycles until they are purified. When they purify themselves, then you may approach them in the manner specified by Allah. Surely Allah loves those who always turn to Him in repentance and those who purify themselves." (alBaqarah: 222)

The Prophet (pbuh) instructs someone who has experienced nocturnal emission on a Friday to take a bath. Taking a bath protects a person from microbes and parasites that live on the skin in abundance due to sweat and others. Washing oneself as a result of janabah creates a feeling of comfort and vigor and stimulates blood circulation. Dr. Zaki Suwaydan said, "Dirty skin and dirt and sweat on the skin block sweat pores. Therefore, one must always be clean, shower, and perform ablution, especially in hot weather" ('Ulwan, 1995, p. 47). The Apostle (pbuh) guided his ummah to practice five virtuous qualities; in fact, he considered them as the moral nature of men (al-fițrah al-salimah). The Prophet (pbuh) said, "There are five qualities of the moral nature: clipping the nails, removing hair from the armpit, trimming the moustache, circumcision, and shaving pubic hair" (Muslim, n.d., 1/221).

\section{The above is a General Summary of Physical Hygiene Maintenance. Its Details are as Follows Maintenance of Hands}

The hand is the limb that most frequently touches objects. In fact, it, alongside the feet, is the part of human that is most exposed to germs and dirt. Ablution, thus, cleans, purifies, and removes them of any impurities, "...and your hands up to the elbows..." (al-Ma'idah: 6).

The Apostle of Allah (pbuh) said in an authentic hadith, "Ten qualities of the moral nature: letting the beard grow, clipping the nails, trimming the moustache, washing the joints, removing armpit hair, shaving pubic hair, using miswak, rinsing the nose, and washing with water after relieving oneself." Zakariyya said, "Muș'ab said, 'I have forgotten the tenth, unless it was rinsing the mouth.'" (Muslim, n.d., p. 261)

Likewise, it was authentically narrated that "when the Prophet (pbuh) wanted to eat or drink, he would wash his hands before eating and drinking" (Abu Dawud, 2009, p. 222).

The Prophet (pbuh) instructed to eat with only with the right hand to protect one's health. Educating a boy on how to eat, he said, "Dear child, mention Allah's name, eat with your right hand, and eat from what is next to you." (al-Bukhari, 2002, 3/1599)

Dr. Gharib Jum 'ah said, "The left hand may be exposed to microbes and parasites because it is used to clean after relieving oneself (istinja')." The Prophet (pbuh) said in an authentic hadith, "When one of you wakes up from his sleep, he must not put his hand in the water vessel unless he washed it three times, for he does not know where his hand was while he slept" (Jum 'ah, 2007, p. 50). 


\section{Prevention during Drinking}

"It was narrated authentically from the Prophet (pbuh) that he forbade turning the waterskin upside down, that is, to turn its mouth upside down and drink directly from it. Scholars interpreted that his forbidding of such an action is that it will cause the mouth to smell unpleasant. Constantly drinking this way would cause the mouth's odor to become foul" (Jum'ah, 2007, p. 50).

Others stated that the waterskin may contain insects or other creatures, such as snakes. Imam Ibn al-Athir said, "Another hadith permitted it (that is, drinking from waterskins). This may suggest that the Prophet's (pbuh) prohibition pertains to only a large water container, not a small one" (al-Bukhari, 2002, 10/5625).

\section{Spiritual Prevention}

It was narrated authentically that the Apostle (pbuh) declared about prayer, "If anyone keeps to it, it will be light, evidence and salvation for him on the day of resurrection. But if anyone does not keep to it, it will not be for him light, evidence, or salvation, and on the day of resurrection he will be associated with Qarun, the Pharaoh, Haman, and Ubayy ibn Khalaf." He also said, "If one of you becomes frightened during sleep, he should say, "I seek refuge in God's Perfect Words from His anger, His punishment, the evil of His servants, and the evil suggestions of the devils and their presence,' so that they will not harm him. 'Abd Allah used to teach them to his children who have and have not reached puberty. He wrote them down on a sheet and hung it on the child's neck" (al-Tirmidhi, n.d.).

\section{Prophetic Commandments to Prevent Outbreaks}

- The Apostle (pbuh) said, "Whoever recites 'In the Name of Allah, Who with His Name nothing can cause harm in the earth nor in the heavens, and He is the All-Hearing, the All-Knowing' three times, he would not be struck by a sudden calamity until the morning. Whoever recites it three times in the morning, he would not be struck by a sudden calamity until the evening" (Sunan Abi Dawud). The Prophet (pbuh) also instructed Muslims to regularly supplicate, "There is no God worthy of worship except You. Glory be to You! I have certainly done wrong." Allah says, "And [remember] when the Man of the Whale stormed off [from his city] in a rage, thinking We would not restrain him. Then in the [veils of] darkness he cried out, "There is no God [worthy of worship] except You. Glory be to You! I have certainly done wrong." (alAnbiya': 87).

The Prophet (pbuh) said, "The supplication of Dhu al-Nun (Prophet Yunus) in the belly of the whale, 'There is no God worthy of worship except You. Glory be to You! I have certainly done wrong,' if supplicated by a person for anything, it will be granted by Allah" (al-Tirmidhi, n.d., 3505). The Apostle (pbuh) "sought refuge in Allah from the distress of trial, being overtaken by a tribulation, malicious rejoicing of enemies, and perversity of fate" (al-Bukhari, 2002, p. 256).

- Anas ibn Malik narrated that the Prophet (pbuh) said, "When someone exits his house and says, 'In the name of God; I trust in God; there is neither might nor power but in God,' the following will be said to him at that time, 'You are guided, defended, and protected.' The devil will steer clear of him, and another devil will say, 'How can you deal with a man who has been guided, defended and protected?'” (Abu Dawud, n.d., 3426). 'Abd Allah ibn 'Umar said, "The Apostle (pbuh) never forgot these supplications in the morning and evening, 'O Allah, I ask You for well-being in this world and in the Hereafter. O Allah, I ask You for forgiveness and well-being in my religious and my worldly affairs and my family and wealth. $O$ Allah, conceal 
my faults, calm my fears, and protect me from before me and behind me, from my right and $\mathrm{my}$ left, and from above me, and I seek refuge in You from being taken unaware from beneath me'" (Hanbal, 2009, 11/7).

'Abd Allah ibn 'Amir narrated, "Umar traveled to Sham. When he reached Sargh, he received news that an epidemic (of plague) had broken out in Sham. 'Abd al-Rahman ibn 'Auf told him that the Apostle of Allah (pbuh) said, 'If you hear that it (plague) has broken out in a land, do not enter it. If it breaks out in a land where you are present, do not go out escaping from it.'" (al-Bukhari, 2002, 5728). Abu Hurayrah narrated that the Apostle of Allah (pbuh) said, "The ill shall not be taken to the healthy" (al-Bukhari, 2002, 1422). Anas narrated that the Apostle of Allah (pbuh) said, "Virtuous deeds protect from evil fates, diseases, and calamity. The people of correctness in this world are the people of correctness in the next world" (al-Bukhari, 2002, 1422). The Apostle of Allah said, "Cover the vessels and tie the waterskins, for every year there is a night where pestilence descends. The pestilence shall fall into uncovered vessels and untied waterskins" (Muslim, n.d., 6/142).

\section{Significance of Cleanliness and Environmental Preservation to Prevent Diseases The Significance of Cleanliness is Two-fold \\ - Preventing diseases and spread of infection \\ - Improving living conditions and preventing accidents and nervous tensions.}

\section{Preventative, not Curative, Health Lessons}

First: Maintaining body, hand, teeth, nail, and hair hygiene, in addition to the cleanliness of clothing, food, streets, homes, cities, and water sources such as rivers and wells.

Second: Preventing infectious diseases by quarantining, sterilizing hands before and after meeting the sick, taking medication and remedy, and vaccination for prevention and treatment.

Third: Avoiding food that is harmful to health, such as eating forbidden foods like dead animal, blood, pork, drugs, and alcohol, as well as encouraging eating good meat.

Fourth: Paying attention to sexual health by forbidding adultery and homosexuality.

Fifth: Psychological and mental health by forbidding the causes of nervous tension with the help of faith in Allah and His destiny, as well as patience in the face of adversity, distress, and calamity.

Sixth: Encouraging attention to the physique and urging community service, manual work, and movement by encouraging sports such as wrestling, horse riding, swimming, throwing, fencing, and all kinds of racing, while discouraging obesity, abdominal obesity, and inactivity.

\section{Like Prevention, Islam also Deems Treatment as Important Environmental Health in Islam}

Islam considers cleanliness as an act of devotion. When embracing Islam, one has to take a bath before witnessing that there is no God but Allah and that Muhammad is the Apostle of Allah. Likewise, ablution is required before a prayer.

A Muslim takes good care of oral hygiene by rinsing his mouth, using miswak, and cleaning between the teeth. A Muslim also takes care of the cleanliness of containers and keeps them closed, as well as avoiding the pollution of rivers and wells. Islamic scholars considered water that has come in contact with urine or feces as impure. Similarly, Muslims take care of the cleanliness of their homes, streets, and city. 


\section{Guidance of the Sunnah to Fight Outbreaks}

\section{Islamic Teachings in this Area have Preceded Modern Medicine, among them}

Instructing the isolation of an infectious patient from healthy people. The infectious patient may cause another person to fall ill until the period of infection passes. The noble Apostle (pbuh) established the principle of quarantine, i.e., isolating a patient who is not expected to be cured, such as a leper. Islam defines a rule in dealing with an epidemic. The Apostle (pbuh) said, "If you hear that it (plague) has broken out in a land, do not enter it. If it breaks out in a land where you are present, do not go out escaping from it" (al-Bukhari, 2002, p. 5728).

Islam forbids sneezing in another's face, as it may spread influenza and sore throat. The Apostle of Allah (pbuh) said, "If one sneezes, he must cover his face with his palms or the end of his garment" (al-Tirmidhi, n.d., p. 2745).

\section{Conclusion}

This study has shown that Islam is the true religion and Prophet Muhammad (pbuh) was the first teacher of mankind. The study has arrived at several findings, the most important of them are:

1. Conducting studies and publishing articles about the Prophetic guidance to prevent diseases and outbreaks.

2. Education authorities in the Islamic world should include this topic in their curricula.

3. Media authorities should disseminate this research topic in their programs through various forms of media.

4. Waqf ministries and authorities, especially those overseeing sermons, lectures, and lessons, should include the research topic of Prophetic guidance to prevent diseases and outbreaks in their plans.

\section{References}

The Holy Quran.

Abdelgelil, M. F. M. (2020). Grammarians' Critique of Qur'anic Qira'at. International Journal of Academic Research in Business and Social Sciences, 10(11), 1225-1231. Abdelgelil, M. F. M. (2020). Solving the Quranic Issues with Quranic Qira'at, International Journal of Academic Research in Business and Social Sciences, 10(12), 36-42.

Abdelgelil, M. F. M., Al-Janayni, M. U., Baru, R., Hamzah, M. S., Razali, M. A. T. M., \& Ismail, F. Z. (2018). Tawjih Al-Qira'at Based on Inscription, Language, and Unusual Modes of Recitation According to Ibn Zanjalah. International Journal of Academic Research in Business and Social Sciences, 8(10), 362-370.

Abdelgelil, M. F. M., Alshaheri, Y. M. A., Subagio, M. H. M., Hassan, A. F., Othman, A. K. I., \& Omar, N. (2021). The Languages of the Arabs and Their Relationship to The Qiraat in The Interpretation of Ibn Ajiba. International Journal of Academic Research in Business and Social Sciences, 11(9), 759-765.

Abdelgelil, M. F. M., Daud, N. B., Omar, N. B., Ismail, F. Z. B., \& Wahab, A. H. B. A. (2018). Taujeeh Al-Qira'at Using Qur'an, Hadith and Poetry according to Ibn Zanjalah. International Journal of Academic Research in Business and Social Sciences, 8(10), 371-379.

Abdelgelil, M. F. M., Hasan, A. F., Yusoh, F, El khayat, M. H. M., Razali, M. A., Ismail, F. Z., \& Ab Rashid, R. (2021). Correlation Between Irregular Qiraat And Arabic Linguistics In The Quranic Tafseer Book By Al-Razi. International Journal of Academic Research in Business and Social Sciences, 11(7), 1632-1639. 
Abdelgelil, M. F. M., Hasan, A. F., Yusoh, F., Ismail, F. Z., Ab Rashid, R., Ab Aziz, N. S., Hassan, A. (2021). The Impact of Irregular Qiraat on Arabic Semantics and Dialects. International Journal of Academic Research in Business and Social Sciences, 11(7), 1672-1676.

Abdelgelil, M. F. M., Hasan, A. F., Yusoh, F., El khayat, M. H. M., Razali, M. A., Hassan, A., Ab Aziz, N. S. (2021). Arabic Syntactic Rules with Reference to Quranic Qurra. International Journal of Academic Research in Business and Social Sciences, 11(7), 1707-1711.

Abdelgelil, M. F. M., Hassan, A., Yusof, N. H., Idris, M. F. H., Hasan, A. F., \& Ramadan, A. A. (2020). Defending the Quran in the Study of Tawjeeh Al-Qira'at, International Journal of Management, 11(10), pp. 101-104.

Abdelgelil, M. F. M., Musolin, M. H., Serour, R. O. H., Abdullah, M. S., \& Noor, M. N. M. (2018). Law and Moral Values in the Holy Quran. International Journal of Academic Research in Business and Social Sciences, 8(11), 445-451.

Abdelgelil, M. F. M., Osman, M. F. M. A., Serour, R. O. H., Subagio, M. H. M., Othman, A. K. I., \& Hassan, A. F. (2021). The History of the Qur'anic Enigma and the Impact of Interpretation in Directing it. International Journal of Academic Research in Progressive Education and Development, 10(3), 412-418.

Abdelgelil, M. F. M., Othman, A. K. I., Serour, R. O. H., Osman, M. F. M. A., \& Hassan, A. F. (2021). Ibn Qutayba's Response to the Slanderers who Claim Grammatical Mistake in the Qur'an. International Journal of Academic Research in Progressive Education and Development, 10(3), 419-426.

Abdelgelil, M. F. M., Othman, A. K. I., Subagio, M. H. M., Serour, R. O. H., Hassan, A. F., \& Osman, M. F. M. A. (2021). Directing the Enigma of Quranic Words According to Ibn Qutaybah and Al-Far. International Journal of Academic Research in Progressive Education and Development, 10(3), 427-434.

Abdelgelil, M. F. M., Razali, M. A., Hassan, A., Hasan, A. F., Idris, M. F. H., \& Masoud, A. S. (2020). Quranic Inimitability in Quranic Qiraat, International Journal of Management, 11(10), pp. 117-121.

Abu Dawud, S. A. (2009). Sunan Abi Dawud. Investigation: al-Arna'uț. Birut: al. Dar al-Risalah al-'Alamiyyah.

Abu 'Isa, M. T. (N. D). Sunan al-Tirmidhi. Investigation: Mahmud Muhammad Mahmud Hasan. Birut: Dar al-Kutub al-'llmiyyah.

Ahmad, H. (2009). Musnad Ahmad ibn Hanbal. Investigation: al-Arna'uț. Cairo: Al-Maktabah al-Waqfiyyah.

Al-Bukhari, M. I. (2002). Șahih al-Bukhari. Investigation: Muhammad Zuhayr ibn Nașir al-Nașir. Cairo: Dar Tawq al-Najah.

Al-Ghawwabi, H. (1967). Bayna al-Țibb wa al-Islam. Cairo: Dar al-Katib al-'Arabi li al-Nashr.

Jum 'ah, G. (2007). al-Ṭibb fi Daw' al-Islam. Cairo: Markaz al-Kitab li al-Nashr.

Muslim, H. (N. D). Șahih Muslim. Investigation: Naz̧ar Muhammad al-Faryabi. Riyadh: Dar Tayyibah.

Ulwan, F. (1995). Wa fi al-Șalah Șihhah wa Wiqayah wa 'llaj. Cairo: Dar al-Salam li al-Taba'ah wa al-Nashr. 